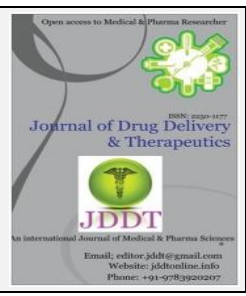

Open Access

Research Article

\title{
Anti-inflammatory activity of Schrebera Swietenioides Roxb. in cream formulation on CD68 expression in mice skin wound
}

\author{
Sharma Piush ${ }^{* 1}$, Singh Charanjeet ${ }^{2}$ \\ ${ }^{1}$ Maharishi Arvind College of Pharmacy, Jaipur, Rajasthan (INDIA) \\ ${ }^{2}$ Biyani Institute of Pharmaceutical Sciences, Jaipur, Rajasthan (INDIA)
}

\begin{abstract}
Aim: The purpose of this study was to determine the potential of Schrebera Swietenioides alcohol leaf extract in cream composition in the expression of immunoglobulin CD68 (macrophage) during the wound healing process in the inflammatory stage of mice skin.

Materials and Methods: Amount of 12 two-months-old male mice were used between 30 and 40 g. To surgical procedures, wound skin incision was performed $2.0 \mathrm{~cm}$ in length until subcutaneous on the paravertebral of each animal. The treatment was carried und er locally anesthetized with procaine cream. The mice were allotted into four groups of each, entire surface of each group wound covered by base cream control, sulfadiazine $0.1 \%$ cream, alcoholic leaves extract of Schrebera Swietenioides cream $10 \%$ and, $15 \%$, respectively. All experiments were performed twice a day for 3 days. The wound healing was assayed in stained histological sections in immunohistochemical of the wounds. CD68 expression was investigated under a microscope.
\end{abstract}

Amount of 12-month-old male mice between 30 and $40 \mathrm{~g}$ was used. For surgical procedures, a $2.0 \mathrm{~cm}$ skin lesion was also performed under the skin on the vertebrae surrounding each animal. Treatment was performed under local anesthetic with procaine cream. Rats were assigned to four groups each, the entire surface of each group of lesions covered by control cream, $0.1 \%$ sulfadiazine cream, alcohol leaf from Schrebera Swietenioides cream respectively at $10 \%$ and at $15 \%$. All tests were performed twice a day for 3 days. The lesions were analyze $d$ in sections of tissue with staining of wound immunochemistry. The expression of CD68 was studied under a microscope.

Results: The results showed that the cream from the $10 \%$ and $15 \%$ alcoholic leaves extract of Schrebera Swietenioides revealed moderate immune reaction to CD68 on wound healing.

Conclusion: We concluded that the alcoholic leaves extract cream of Schrebera Swietenioides possesses anti-inflammatory activity in wound healing process of mice skin.

Keywords: anti-inflammatory, CD68, Schrebera Swietenioides, wound healing

Article Info: Received 12 July 2019; $\quad$ Review Completed 19 August 2019; $\quad$ Accepted 23 August 2019; Available online 15 Sep 2019

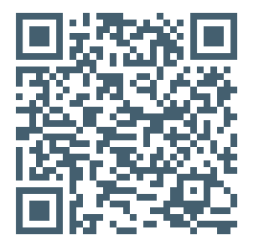

Cite this article as:

Sharma P, Singh C, Anti-inflammatory activity of Schrebera Swietenioides Roxb. in cream formulation on CD68 expression in mice skin wound, Journal of Drug Delivery and Therapeutics. 2019; 9(5):39-42

http://dx.doi.org/10.22270/jddt.v9i5.3541

Dr. Piush Sharma, Professor \& Principal, Maharishi Arvind College of Pharmacy, Jaipur, Rajasthan (INDIA)

\section{INTRODUCTION:}

On the basis of the physiology of wound healing, the wounds can be classified as chronic and acute wounds. Balqis et al. [1] documented that chronic wound appeared in an 18years-old male Elephas maximus sumatranus due to surgical debridement to remove tumor extra skeletal fibrosarcoma in the captive elephant. Acute wounds caused by accidental tripping have been found in wild animals such as tiger, Panthera tigris sumatrae [2]. Indeed, these wounds contribute to substantial morbidities such as increased risk for infection, limb amputation, and animal death. It is understood that there are certain essential drugs present in modern medicine that help in the healing of wounds. There are several growth factors which are having the potential of improving the healing of wounds. Furthermore, a number of antibiotic compounds have been used in the treatment of the bacterial infected wounds. Unfortunately, there is a serious untoward effect such as carcinogenesis can be generated by some of these growth factors [3,4]. Using commercial antibiotic compounds leads to the risk of widespread development of resistant bacteria to most of the current antibiotics. A number of antibiotics resistant can be demonstrated in Staphylococcus aureus bacteria isolated from a human in Mongolia [5], from milk in South Africa [6], and from poultry in Malaysia [7]. Multidrug resistance 
occurred in Escherichia coli strain [8] and Salmonella spp. [9]. Due to the risks, various authors made a new path to introduce alternative wound healing agents from natural origin. The process of wound healing occurs in three phases such as inflammatory, proliferative, and maturation [10] Importantly, the inflammatory phase is naturally intended to remove devitalized tissue and prevent invasive infection [11]. The macrophages are prominent inflammatory cells in wounds. Macrophages are phagocytes, contributing to both innate immunity and cell-mediated immunity. Their function is to stimulate lymphocytes and other immune cells to respond to the pathogens and to phagocytize cellular debris and pathogens $[12,13]$. The CD68 protein belongs to a family of the lysosomal glycoprotein which is specifically expressed by tissue macrophages including Langerhans cells. Macrophages have many functions in wound healing, including host defense, the promotion and resolution of inflammation, the removal of apoptotic cells, and support of cell proliferation and tissue restoration following injury [14] Due to its availability, small size rodent, easy of handling and low cost, mice are used as suitable animal's model for the study of skin wound healing that closely parallels to the healing of human wounds. Various authors choose mice to carry out their study. For wound healing and antimicrobial properties, a study employed by Agra et al. [15] showed that the aqueous extract from Bowdichia virgilioides stem barks can be used in mice. Jiao et al. [16] described that the function of cell-mediated immunity of mice was influenced by flavonoid extracted from stem and leaf of Astragalus membranaceus.

\section{MATERIALS AND METHODS:}

\section{Ethical approval:}

All experimental animal procedures were performed in compliance with the regulation of Animal Ethics Committee. This research was approved by the Animal Ethics Committee of Jaipur College of Pharmacy, Jaipur.

\section{Experimental animals:}

Amount of 12 male mice (Mus musculus) 2 months old and weighing 30-40 g obtained from Jaipur College of Pharmacy, Jaipur, Rajasthan, were used in current study. The mice were housed in individual cages which include drinking water and rations. The mice were fed a standard laboratory diet and given ad libitum access to food and water. The animals were kept for acclimatization for 2 weeks.

\section{Preparation of cream:}

The coarsely powdered (1000 g) oven-dried leaves of Schrebera Swietenioides was extracted with alcohol by using soxhlet apparatus for $20 \mathrm{~h}$. After completion of extraction, the solvent was removed by distillation and concentrated. The Schrebera Swietenioides extract cream made with a base of oil in water $(0 / \mathrm{W})$ according to methods Muntiaha et al. [22]. A cream base was added little by little with the $10 \%$ and $15 \%$ alcoholic extract of Schrebera Swietenioides in a porcelain dish containing 100 $\mathrm{g}$ of cream and stirred until homogeneous at room temperature.

\section{Surgical procedures:}

All mice were anesthetized locally with procaine cream, and one wound skin incision was performed $2.0 \mathrm{~cm}$ in length until subcutaneous on the paravertebral of each animal. The animals were handled in accordance with aseptic principles to avoid exogenous bacterial contamination.

\section{Experimental design:}

Mice were divided into four groups with three mice of each. Group 1(A) as a negative control, the entire surface of wound covered by base cream. Group 2(B) as a positive control, the entire surface of wound covered by sulfadiazine $0.1 \%$ cream both Group 3(C) and Group 4(D) as treatment groups. The $\mathrm{C}$ and $\mathrm{D}$, the entire surface of wound covered by Schrebera Swietenioides extract cream 10\% and 15\%, respectively. The wound was treated twice a day at $08.00 \mathrm{am}$ and 18.00 pm until day 3 .

Histopathological and immunohistochemical expression of CD68:

Wound skin tissue samples were collected in $10 \%$ buffered formalin for histopathological examination [23,24]. The tissues were processed by routine paraffin embedding technique, and $5 \mu \mathrm{m}$ sections were stained with immunohistochemical staining by standard methods as described by Darmawi et al. [25], using streptavidin-biotin complex (SB). For macrophages immunoreaction, we used the CD68 monoclonal mouse antibody (Dako, Carpentaria, CA) at dilution 1:100 in PBS. Immunohistochemical labeling for each antibody was graded on scale of 0-3 Grades according to the following assessment: No detectable labeling (Grade 0), weak or mild labeling (Grade 1), moderate labeling (Grade 2), marked labeling (Grade 3) with local, and/or widespread reactivity as described by Caffo et al. [26].

\section{RESULTS:}

The results of the present study showed that the cream from the $10 \%$ and $15 \%$ alcoholic extract of Schrebera Swietenioides revealed moderate immune reaction to CD68 on wound healing. The CD68 positive cells were especially detected in perivascular area. The CD68 monoclonal mouse antibody had a strong reaction with antigen on the connective tissue macrophages as seen in Figure-1. On day 3 wound healing process mice skin, the expression of CD68 positively reacts in four group treatment. Immunohistochemical examination with SB staining revealed macrophages in all the organs examined. The expression of macrophages in the skin tissue can be identified by the expression of the CD68 marker for a positive result. CD68 positive cells closed to perivascular area. Macrophages were identified as brown color against a pale ground background. Here, we regarded them as Langerhans macrophages.

Our result showed that the mice wound skins covered by base cream had a mild immune reaction to CD68 expression. We found that dramatic change of mice wounds skins in the appearance of CD68 expression treated with sulfadiazine $0.1 \%$. We explained that dramatic changes of mice wound skins were observed in most of treated with Schrebera Swietenioides extract cream groups. Comparatively, the concentration of Schrebera Swietenioides cream 10\% showed less effect than Schrebera Swietenioides extract cream 15\%. Treatment of mice wounds skins with Schrebera Swietenioides extract cream 15\% resulted in dramatic change in moderate immune reaction to CD68 expression as seen in Figure-1. 

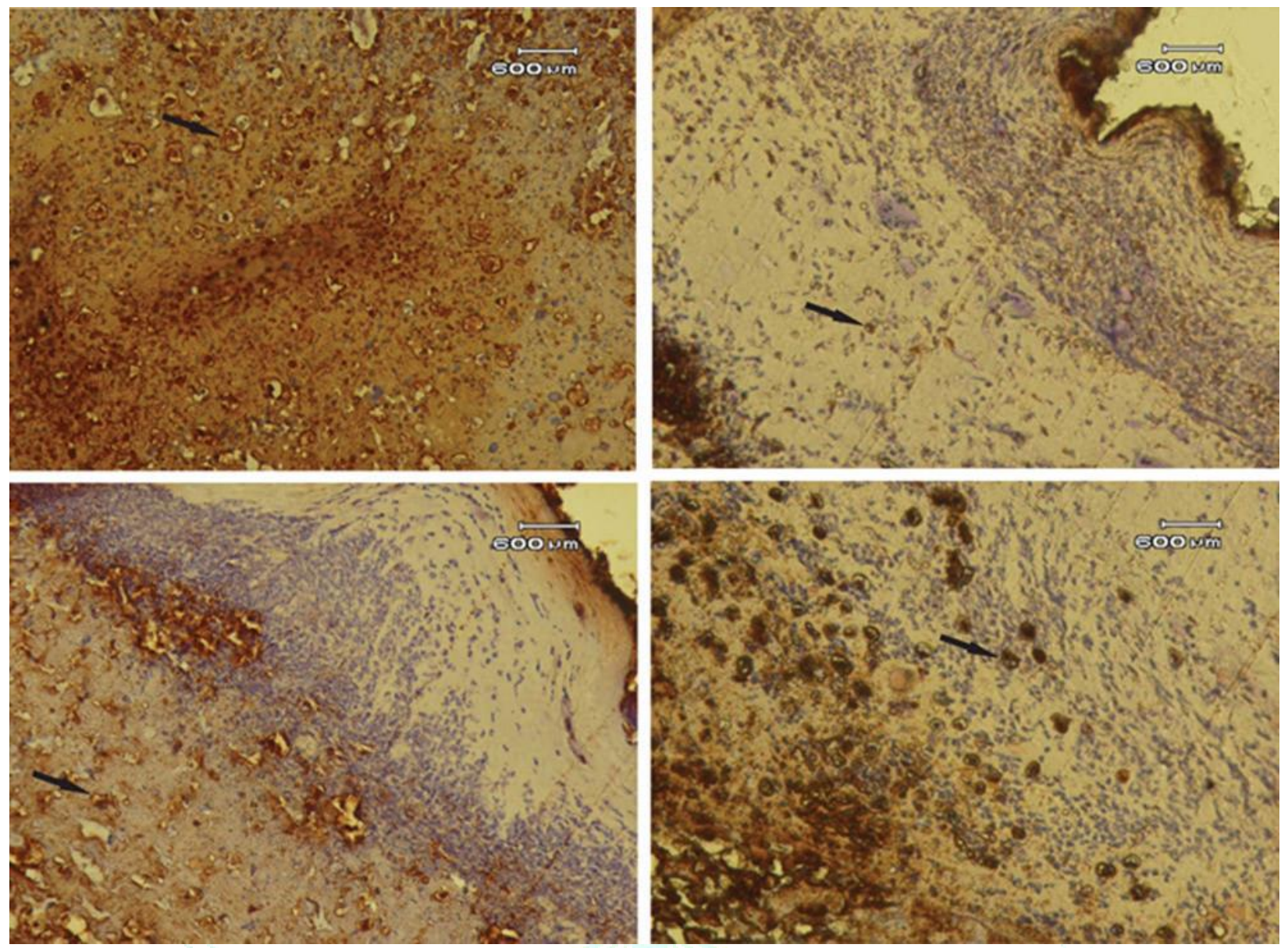

Figure-1: Photomicrograph of wounds skin on day 3 of treatment (streptavidin-biotin 40x). CD68 positive cells each group that marked the brown color (arrow). (a) Minimal immunoreactivity CD68 positive cells on Group A (Grade 1). (b-d) Moderate immunoreactivity CD68 positive cells in Groups B-D (Grade 2).

\section{DISCUSSION:}

The simplest interpretation of our finding is that at least some macrophages go through the wound skins. In the study of Guo et al. [27] showed that immunohistochemical examination CD68 macrophages can determine in the process of wounds healing are more specific than histopathological with routine staining. Macrophages on the tissue can be identified by marker human CD68. Nucera et al. [28] described that CD68 was a $110 \mathrm{kDa}$ transmembrane glycoprotein by human monocytes and macrophages. CD68 can be used for identifying a population of cells being of mononuclear phagocyte origin, assessing the number of macrophages infiltrating a wound healing area. CD 68 expressed by Langerhans cells constitute, the most abundant macrophage population in the skin was observed as a major gateway for wound infection. In another study showed that the majority of macrophages found in the perivascular area of wound healing [29]. In this study, Schrebera Swietenioides extract cream $15 \%$ is an optimum dose that could fasten the inflammatory phase wound healing process. It was found that the process of wound healing in D is better than the other groups.

The present study clearly demonstrated that the CD68 expression on mice wound skins it can be seen that the Schrebera Swietenioides extract cream 15\% have potential as an anti-inflammatory. In support of this hypothesis, many previous reports exist about the effect of using Schrebera Swietenioides alcoholic extract as therapeutic agents that contributes to impaired wound healing process.
The evidence described here argues that the Schrebera Swietenioides alcoholic leaves extract cream is also possibly involved in the early phase of wound healing. In confirmation of our previous study, we found that Schrebera Swietenioides alcoholic leaves extract cream histopathologically could be decreased inflammatory cells infiltration [19]. Various authors noticed that the purpose of inflammation was interesting to plasma protein and phagocytic cells to the wound surface to destroy foreign substances, cell debris, and prepared for the process of wound healing and repair $[27,28,35,36]$. In respect of our results, the finding is similar to those described by Singer and Clark [35], so it seems macrophages were widely distributed in the body and played a role in the process inflammation as the body's reaction to foreign particles and bacteria. It has long been known that the macrophages play an important role in inducing angiogenesis in a manner secrete several factors: Tumor necrosis factor-alpha, VEGF, angiogenin, urokinase, and platelet-derived growth factor. The role of macrophages CD68 on angiogenesis (CD34 marker) in line with research conducted by El-Rouby [36] showed that the number of macrophages, which was widely followed by an increasing amount of angiogenesis.

\section{CONCLUSION:}

We concluded that the alcoholic leaves extract cream of Schrebera Swietenioides possesses anti-inflammatory activity in wound healing process of mice skin.

\section{REFERENCES:}


1. Balqis, U., Budiman, H., Eliza, D. and Sayuti, A. (2010) Case report: Extraskeletal fibrosarcoma in an elephant. Proc. Int. Sem. Syiah Kuala Univ., 1 : 113-115.

2. Darmawi, D., Darniati, Manaf, Z.H., Syafruddin, and Sayuti, A. (2011) Isolation of gram-negative bacteria from metacarpal injury of Panthera tigris sumatrae trapped in Subulussalam. Proc. Ann. Int. Con. (AIC) Syiah Kuala Univ., 1 : 131-135.

3. Raica, M. and Cimpean, A.M. (2010) Platelet-derived growth factor (PDGF)/PDGF receptors (PDGFR) axis as target for antitumor and antiangiogenic therapy. Pharmaceutical, 3: 572-599.

4. Yu, J., Ustach, C. and Kim, H.R.C. (2003) Platelet-derived growth factor signaling and human cancer. J. Biochem. Mol. Biol., 36(1): 49-59.

5. Nair, R., Hanson, B.M., Kondratowicz, K., Dorjpurev, A., Davaadash, B., Enkhtuya, B., Tundev, O. and Smith, T.C. (2013) Antimicrobial resistance and molecular epidemiology of Staphylococcus aureus from Ulaanbaatar, Mongolia. PeerJ, 1: e176.

6. Akindolire, M.A., Babalola, O.O. and Ateba, C.N. (2015) Detection of antibiotic resistant Staphylococcus aureus from milk: A public health implication. Int. J. Environ. Res. Pub. Health, 12: 1025410275.

7. New, C.Y., Amalia, A.R., Ramzi, O.S.B. and Son, R. (2016) Antibiotic resistance evolution of methicillin resistant Staphylococcus aureus (MRSA) and colloidal silver as the nan weapon. Int. Food Res. J., 23(3): 1248-1254.

8. Adefisoye, M.A. and Okoh, A.I. (2016) Identification and antimicrobial resistance prevalence of pathogenic Escherichia coli strains from treated wastewater effluents in Eastern Cape, South Africa. Microbiol. Open, 5(1): 143-151.

9. Odjadjare, E.C. and Olaniran, A.O. (2015) Prevalence of antimicrobial resistant and virulent Salmonella spp. in treated effluent and receiving aquatic milieu of wastewater treatment plants in Durban, South Africa. Int. J. Environ. Res. Pub. Health, 12: 9692-9713.

10. Kumar, V., Khan, A.H. and Nagaraja, N. (2013) Animal models for the evaluation of wound healing activity. Int. Bull. Drug Res. 3(5): 93-107.

11. Prasetyono, T.O.H. (2009) General concept of wound healing Med. J. Indones., 18(3): 208-216.

12. Song, L., Lee, C. and Schindler, C. (2011) Deletion of the murine scavenger receptor CD68. J. Lipid. Res., 52: 1542-1550.

13. Chistiakov, D.A., Killingsworth, M.C., Myasoedova, V.A., Orekhov, A.N. and Bobryshev, Y.V. (2017) CD68/macrosialin: Not just a histochemical marker. Lab. Invest., 97: 4-13.

14. Koh, T.J. and DiPietro, L.A. (2011) Infammation and wound healing: The role of the macrophage. Expert Rev. Mol. Med., 13: 1-11.

15. Agra, I.K.R., Pires, L.L.S., Carvalho, P.S.M., Silva- Filho, E.A., Smaniotto, S. and Barreto, E. (2013) Evaluation of wound healing and antimicrobial properties of aqueous extract from Bowdichia virgilioides stem barks in mice. An. Acad. Bras. Cienc., 85(3): 945-954.

16. Jiao, Y., Wen, J., Yu, X. and Zhang, D. (2001) Influence of flavonoid of Astragalus membranaceus's stem and leaf on the function of cell mediated immunity in mice. Chineese J. Integrated. Trad. Western Med., 7(2): 117-120.

17. Bosser J, Rabevohitra R.(1985) "The genus Scherebera found in madagascar, Bull Mus Nation hist nat paris, 4(7):59- 66.

18. Hansraj Manda. (2009) "Antioxidant, anti- Inflammatory and antipyretic activities of ethyl acetate fraction of ethanolic extract of Schrebera swietenioides". Roxb. root, IJTPR, 1(1): 711.

19. Nambiar. V. P. K. (1996) "Indian Medicinal Plants: A Compendium of 500 Species". 5th edition, Orient Longman Private ltd, Annasalai, Chennai: 88-95.
20. Rajkumar S. Bagali (2010) "Evaluation of antidiabetic and antioxidant effect of Schrebera swietenioides fruit ethenolic extract”. Der Pharmacia Lettre, 2(5): 278- 288.

21. Rasal AS, (2009) "Evaluation of the healing potential of Schrebera swietenioides in the dexamethasone-suppressed wound healing in rodents" Int J Low Extrem Wounds., 8(3):14752.

22. Muntiaha, M.C., Yamlean, P.V.Y. and Lolo, W.A. (2014) Test effectivity Jatropha multifida L. to heal wound infection cause by Staphylococcus aureus in rabbit (Orytolagus cuniculus). Pharmacon, 3(3): 294-302.

23. Darmawi, D., Balqis, U., Hambal, M., Tiuria, R., Frengki, and Priosoeryanto, B.P. (2013) Mucosal mast cell response in jejunum of Ascaridia galli-infected laying hens. Med. Peternak., 36(2): 113-119.

24. Balqis, U., Hambal, M., Rinidar, Athaillah, F., Ismail, Azhar, Vanda, H. and Darmawi, D. (2017) Cuticular surface damage of Ascaridia galli adult worms treated with Veitchia merrillii betel nuts extract in vitro. Vet. World, 10(7): 732-737.

25. Darmawi, D., Balqis, U., Hambal, M., Tiuria, R., Priosoeryanto, B.P. and Handharyani, E. (2012) The ability of immunoglobulin yolk recognized the antigen in the tissue of Ascaridia galli. Med. Peternak., 35(3): 190-195.

26. Caffo, M., Caruso, G., Barresi, V., Pino, M.A., Venza, M., Alafaci, C. and Tomasello, F. (2012) Immunohistochemical study of CD68 and CR3/43 in astrocytic gliomas. J. Anal. Oncol., 1: 42-49.

27. Guo, X., Liu, L., Zhang, M., Bergeron, A., Cui, Z. and Dong, J. (2009) Correlation of CD34+ cells with tissue angiogenesis after traumatic brain injury in a rat model. J. Neurotrauma., 26(8): 1337-1344.

28. Nucera, S., Biziato, D. and Palma, M.D. (2010) The interplay between macrophages and angiogenesis in development tissue injury and regeneration. Int. J. Dev. Biol., 55: 495-503.

29. Esimone, C.O., Nworu, C.S. and Jackson, C.L. (2008) Cutaneous wound healing activity of a herbal ointment containing the leaf extract of Jatropha curcas L. (Euphorbiaceae). Int. J. Appl. Res. Nat. Prod., 1: 1-4.

30. Laxane, S.N., Swarnkar, S., Mruthunjaya, K., Zanwar, S.B. and Setty, M. (2013) Jatropha curcas: A systemic review on pharmacological, phytochemical, toxicological profiles and commercial applications. Res. J. Pharmaceut. Biol. Chem. Sci., 4(1): 989-1010.

31. Ogunnaike, B.F., Okutachi, I.R., Anucha, E.S., Gbodi, O.O. Shokunbi, O.S., and Onajobi, F.D. (2013) Comparative antiinflammatory activities of Jatropha curcas, Ocimum gratissimum and Solanum scabrum leaves. J. Nat. Prod. Plant Resour., 3(1): 5966.

32. Oskoueian, E., Abdullah, N., Saad, W.Z., Omar, A.R., Ahmad, S., Kuan, W.B., Zolkifli, N.A., Hendra, R. and Ho, Y.W. (2011) Antioxidant, anti-inflammatory and anticancer activities of methanolic extracts from Jatropha curcas Linn. J. Med. Plants Res., 5(1): 49-57.

33. Barku, V.Y.A., Boye, A. and Ayaba, S. (2013) Phytochemical screening and assesment of wound healing activity of the leaves of Anogeisus leiocarpus. Eur. J. Exp. Biol., 3(4): 18-25.

34. Kimura, Y., Sumiyoshi, M., Kawahira, K. and Sakanaka, M. (2006) Effects of ginseng saponins isolated from red ginseng roots on burn wound healing in mice. Br. J. Pharmacol., 148: 860-870.

35. Singer, A.J. and Clark, R.A.F. (1999) Cutaneous wound healing. $N$. England Med., 34(10): 738-746.

36. El-Rouby, H.D. (2010) Association of macrophages with angiogenesis in oral verrucous and squamous cell carcinomas. $J$. Oral Pathol. Med., 39: 559-564. 